\title{
Faktor Pemicu Kecemasan Siswa dalam Melakukan Pembelajaran Daring di Masa Pandemi Covid-19
}

\author{
Dwi Hardani Oktawirawan \\ Fakultas Psikologi, Universitas Surabaya, Jl. Raya Kalirungkut, Surabaya, Indonesia \\ Correspondence email: dhoktawirawan@gmail.com
}

\begin{abstract}
Abstrak. Siswa di Indonesia melakukan pembelajaran secara daring dari rumah sebagai upaya pembatasan sosial selama pandemi covid-19. Tujuan dari penelitian ini adalah untuk mengetahui pemicu kecemasan yang dialami oleh siswa serta upaya yang dilakukan untuk mengatasi kecemasan tersebut. Penelitian ini melibatkan 74 informan yang merupakan siswa sekolah menengah atas di Indonesia. Informan diminta untuk mengisi pertanyaan terbuka terkait topik penelitian melalui formulir daring. Hasil penelitian menunjukkan bahwa pemicu kecemasan siswa selama pembelajaran daring antara lain kesulitan memahami materi, kesulitan mengerjakan tugas-tugas, ketersediaan dan kondisi jaringan internet, kendala teknis, dan kekhawatiran akan tugas selanjutnya. Upaya yang dilakukan untuk mengatasi kecemasan tersebut antara lain belajar mandiri, segera mengerjakan tugas yang diberikan, diskusi dengan guru dan teman, berdoa, menyemangati diri sendiri, serta melakukan aktivitas lain seperti menonton film, mendengarkan musik, bermain game, tidur, makan, dan olahraga.
\end{abstract}

Kata kunci: Kecemasan; Pandemi; Pembelajaran Daring; Siswa

\begin{abstract}
Students in Indonesia conduct online learning from home in an effort to socially distancing during the covid-19 pandemic. The purpose of this study is to determine the triggers of anxiety experienced by students and the efforts made to overcome these anxieties. This study involved 74 informants who were high school students in Indonesia. Informants were asked to fill in open questions related to research topics through online forms. The results showed that the triggers for students' anxiety during online learning are difficulty understanding the material, difficulty working on assignments, the availability and condition of the internet network, technical obstacles, and concerns about subsequent assignments. The efforts made to overcome these anxieties are self-study, immediate work on assignments, discussion with teachers and friends, praying, self-encouraging, and doing other activities such as watching movies, listening to music, playing games, sleeping, eating, and doing sports.
\end{abstract}

Keywords: Anxiety; Online Learning; Pandemic; Students

\section{PENDAHULUAN}

Pada bulan Maret 2020 lebih dari 800 juta siswa di dunia melakukan pembelajaran di rumah sebagai akibat dari pandemi covid-19 (Arika, 2020). Menteri Pendidikan dan Kebudayaan (Mendikbud) Indonesia juga membuat kebijakan terkait belajar di rumah bahkan membatalkan ujian nasional 2020 (Asmara, 2020). Kebijakan belajar di rumah ini dilakukan untuk mengurangi interaksi fisik sebagai upaya pencegahan penularan virus corona jenis baru atau covid-19. Mendikbud berharap dengan diterapkannya pembelajaran daring atau jarak jauh ini siswa juga mendapatkan pengalaman baru dalam proses belajar (Fajar, 2020).

Pembelajaran yang dilakukan secara daring memiliki beberapa kelebihan dalam penerapannya. Pembelajaran daring membuat kegiatan belajar mengajar menjadi dapat dijangkau dari berbagai waktu dan tempat (Shukla, Dosaya, Nirban, \& Vavilala, 2020). Penggunaan media daring juga memungkinkan siswa untuk mendapatkan informasi yang lebih luas melalui internet (Hastini, Fahmi, \& Lukito, 2020). Pemanfaatan teknologi ini dianggap sangat membantu dalam melangsungkan pembelajaran selama pembatasan sosial di masa pandemi covid-19 (Pakpahan \& Fitriani, 2020). Generasi siswa saat ini juga dekat dengan teknologi sehingga lebih mudah untuk beradaptasi dengan pembelajaran daring (Hastini et al., 2020).

Berbagai kendala juga muncul dalam penerapan pembelajaran daring. Pembelajaran melalui internet menjadi hal yang sulit dilakukan di beberapa daerah tertentu dengan jaringan yang tidak memadai (Hastini et al., 2020). Penggunaan kuota internet juga memunculkan pengeluaran biaya baru yang bisa menjadi masalah bagi beberapa siswa yang mengalami kesulitan finansial (Morgan, 2020). Kesuksesan dari penerapan pembelajaran daring juga tergantung dari kesiapan sekolah penyelenggara serta guru pengajar (Rusdiana \& Nugroho, 2020). Tidak semua guru mampu menyampaikan keseluruhan materi dengan optimal melalui sistem pembelajaran daring (Morgan, 2020).

Penerapan kebijakan belajar di rumah membuat sebagian siswa merasa cemas dan tertekan. Banyaknya tugas yang diberikan oleh guru membuat banyak siswa merasa stres dalam menjalani pembelajaran daring (Chaterine, 2020). Tidak hanya banyak, tugas yang diberikan oleh guru juga dianggap memberatkan dan memiliki waktu pengerjaan yang sangat singkat sehingga membuat siswa kebingungan dalam menyelesaikan tugas-tugasnya (Raharjo \& Sari, 2020). Dengan banyaknya tugas yang diberikan siswa bisa menghabiskan waktu dari pagi hingga malam hari hanya 
untuk menyelesaikan berbagai tugas daringnya. Kondisi tersebut sebelumnya tidak terjadi ketika kegiatan belajar mengajar masih dilakukan di sekolah.

Penelitian ini bertujuan untuk menggali permasalahan-permasalahan yang dialami oleh siswa selama pembelajaran daring hingga menimbulkan tekanan atau kecemasan. Penelitian akan difokuskan pada siswa jenjang menengah atas yang dianggap memiliki tanggung jawab yang lebih besar mengingat ke depannya akan segera menghadapi pendidikan lebih tinggi di perkuliahan bahkan segera masuk di dunia kerja. Diharapkan melalui penelitian ini didapatkan gambaran mengenai berbagai permasalahan yang mengganggu siswa dalam proses pembelajaran daring sehingga dapat dijadikan acuan untuk evaluasi, perbaikan, atau pembuatan kebijakan di masa mendatang.

\section{METODE PENELITIAN}

Penelitian ini menggunakan metode kualitatif dengan melibatkan 74 informan yang merupakan siswa SMA $(n=26)$, SMK $(n=31)$, dan MA $(n=17)$ dari berbagai daerah di Indonesia. Pengambilan data dilakukan menggunakan survei daring dimana informan diminta untuk mengisi beberapa pertanyaan terbuka terkait pengalamannya melakukan pembelajaran daring. Secara spesifik pertanyaan utama yang harus dijawab oleh informan adalah mengenai pemicu tekanan atau kecemasan yang dialami ketika melakukan pembelajaran daring beserta solusi atau upaya yang dilakukan untuk mengatasi kecemasan tersebut. Data yang diperoleh dari informan kemudian dianalisis dan dikelompokkan berdasarkan tema-tema yang lebih luas.

\section{HASIL DAN PEMBAHASAN}

Pembelajaran daring dilakukan menggunakan berbagai macam media. Media pembelajaran yang paling banyak digunakan oleh informan adalah Google Classroom (77\%) dan Whatsapp (66\%). Banyaknya penggunaan Google Classroom sebagai media pembelajaran daring tidak terlepas dari banyaknya fitur yang diberikan dalam aplikasi tersebut (Zhafira, Ertika, \& Chairiyaton, 2020). Guru dapat membagikan berbagai materi dan tugas kepada siswa dengan mudah melalui Google Classroom. Whatsapp juga dianggap mudah digunakan sebagai media pembelajaran daring mengingat sebelumnya aplikasi ini juga sudah menjadi media komunikasi sehari-hari (Zhafira et al., 2020).

Tabel 1. Pemicu Kecemasan

\begin{tabular}{lc}
\hline \multicolumn{1}{c}{ Kategori } & Frekuensi \\
\hline Kurang memahami materi & 14 \\
Deadline tugas & 14 \\
Internet tidak stabil & 13 \\
Kesulitan mengerjakan tugas & 12 \\
Kesulitan membeli kuota internet & 7 \\
Kendala teknis & 7
\end{tabular}

Penurunan nilai $\quad 6$

Terlambat mengikuti kelas $\quad 5$

Tidak siap menghadapi jenjang selanjutnya 4

Pemahaman yang kurang terhadap materi serta waktu pengerjaan tugas yang singkat membuat siswa merasa tertekan. Kurangnya penguasaan materi membuat siswa kesulitan dalam mengerjakan tugastugas yang diberikan. Hal tersebut memunculkan kecemasan bagi siswa mengenai potensi penurunan nilai ujian hingga ketidaksiapannya dalam menghadapi tingkat berikutnya. Siswa khawatir apabila ketika pembelajaran sudah kembali normal mereka tidak bisa mempelajari materi baru dengan baik karena tidak paham dengan materi sebelumnya. Kondisi tersebut juga dikhawatirkan dapat mempengaruhi kemampuannya setelah lulus dari sekolah, baik itu melanjutkan perkuliahan maupun bekerja.

Tidak semua guru dan siswa siap dalam menghadapi perubahan sistem pembelajaran di masa pandemi ini (Morgan, 2020). Kondisi ini menuntut guru perlu terampil dalam menerapkan berbagai cara untuk melakukan pembelajaran daring dengan efektif (Kaufmann \& Vallade, 2020). Guru yang tidak pernah menggunakan media daring harus berusaha lebih keras untuk menyesuaikan kemampuannya dengan tuntutan saat ini. Begitu pula siswa perlu lebih mandiri dalam mempelajari materi sehingga lebih mudah dalam mengikuti proses pembelajaran daring yang sedang berlangsung (Rusdiana \& Nugroho, 2020).

Koneksi internet menjadi masalah yang cukup berpengaruh dalam proses pembelajaran daring. Siswa merasa cemas jika kesulitan mengikuti pembelajaran daring ketika tidak mampu membeli kuota internet. Selain itu kondisi jaringan yang tidak stabil membuat siswa takut apabila terjadi berbagai kendala teknis. Kendala teknis yang dimaksud antara lain seperti tugas yang tidak berhasil terkirim, terlambat mengikuti kelas, hingga kesulitan mendengarkan penjelasan guru dengan baik. Perbedaan akses teknologi yang dimiliki setiap siswa membuat beberapa siswa kesulitan dalam mengikuti pembelajaran dengan lancar (Morgan, 2020). Kesulitan tersebut semakin terasa bagi siswa yang tinggal di daerah-daerah yang tidak memiliki jaringan internet memadai (Hastini et al., 2020).

Sebagai upaya mengatasi kecemasan yang dialami, siswa berusaha untuk belajar secara mandiri agar dapat memahami materi dengan baik. Tugas-tugas yang diberikan juga segera dikerjakan sesuai kemampuan agar tidak semakin menumpuk. Selain itu siswa juga melakukan diskusi dengan guru dan temantemannya untuk mengerjakan tugas maupun mempelajari materi yang sulit. Kemandirian siswa memang berperan dalam terciptanya keberhasilan pembelajaran daring (Rusdiana \& Nugroho, 2020). Komunikasi yang baik antara pengajar dengan siswa juga menjadi hal yang penting dalam mewujudkan 
pembelajaran daring yang efektif (Kaufmann \& Vallade, 2020; Shukla et al., 2020). Adanya umpan balik positif dari pengajar juga membuat proses pembelajaran daring menjadi lebih menyenangkan bagi siswa (Pakpahan \& Fitriani, 2020).

Tabel 2. Upaya Mengatasi Kecemasan

\begin{tabular}{lc}
\hline \multicolumn{1}{c}{ Kategori } & Frekuensi \\
\hline Belajar mandiri & 12 \\
Segera mengerjakan tugas & 11 \\
Diskusi dengan teman & 10 \\
Konsultasi dengan guru & 10 \\
Tidur & 8 \\
Pasrah dan sabar & 7 \\
Menikmati musik atau film & 7 \\
Menyemangati diri sendiri & 5 \\
Berdoa & 4 \\
Mencari koneksi internet bagus & 4 \\
Olahraga & 2 \\
Minum kopi atau makan & 2 \\
Bermain game & 1 \\
\hline
\end{tabular}

Menerima kenyataan yang ada menjadi pilihan solusi bagi siswa untuk mengurangi kecemasan dalam menjalani pembelajaran daring. Siswa berusaha menguatkan diri sendiri agar tetap semangat melakukan aktivitas belajar di rumah. Siswa juga berdoa kepada Tuhan agar diberi kekuatan dan kelancaran dalam menghadapi berbagai tantangan selama melakukan kegiatan belajar daring. Kemampuan spiritual seperti menerima kondisi yang ada dan mencari makna dari sebuah masalah dapat mengurangi stres yang dialami oleh seseorang (Ahmad \& Ambotang, 2020). Berdoa atau ibadah dianggap mejadi salah satu usaha yang dapat dilakukan untuk menyelesaikan permasalahan fisik maupun psikis yang dialami (Saifuddin, 2019).

Aktivitas lain dilakukan oleh siswa untuk menghilangkan tekanan dan kecemasan yang dirasakan. Aktivitas yang dilakukan antara lain mendengarkan musik, menonton televisi atau film, makan, minum kopi, dan olahraga. Beberapa siswa juga memilih untuk tidur agar merasa lebih tenang dan terhindar dari kecemasan yang berlebihan. Mendengarkan musik dianggap mampu membuat suasana menjadi lebih tenang dan tidak bosan untuk belajar (Izzah, Rahmawati, \& Humairoh, 2020). Aktivitas menghindar seperti menonton televisi, bermain game, dan tidur memang mampu membuat siswa terhindar dari perasaan cemas. Namun apabila dilakukan secara terus menerus juga dapat menimbulkan masalah yang lebih serius karena penyebab dari kecemasan yang dialami justru tidak ditangani (Mukminina \& Abidin, 2020).

\section{SIMPULAN}

Pembelajaran daring yang dilakukan selama masa pandemi covid-19 menimbulkan kecemasan atau tekanan bagi beberapa siswa. Kecemasan tersebut muncul karena siswa kurang memahami materi, kesulitan mengerjakan tugas dengan baik sesuai batas waktu, memiliki keterbatasan dalam mengakses internet, menghadapi berbagai kendala teknis, dan merasa khawatir menghadapi materi di tingkat selanjutnya. Berbagai upaya dilakukan siswa untuk mengatasi kecemasan yang dialaminya. Siswa berusaha untuk belajar mandiri, mengerjakan tugas semampunya, serta diskusi dengan teman dan guru agar mampu memahami materi dengan baik. Siswa juga mencoba sabar, menyemangati diri, dan berdoa agar mendapatkan kekuatan dalam menjalani pembelajaran daring. Aktivitas lain yang dilakukan untuk menurunkan kecemasan adalah tidur, mendengarkan musik, menonton televisi atau film, bermain game, makan, minum kopi, dan olahraga.

Penelitian ini diharapkan mampu menjadi salah satu referensi dalam menerapkan sistem pembelajaran secara daring yang ramah siswa. Sehingga tercipta sistem pembelajaran daring yang lebih optimal dan dapat dijangkau oleh seluruh siswa dari berbagai kalangan. Penelitian berikutnya dapat dilakukan dengan wawancara guna memperdalam gambaran kecemasan yang dialami oleh siswa selama pembelajaran daring. Efektivitas atau keberhasilan dari strategi siswa dalam mengatasi kecemasan juga dapat dikaji lebih lanjut untuk mendapatkan gambaran yang lebih menyeluruh.

\section{DAFTAR PUSTAKA}

Ahmad, A. A. B., \& Ambotang, A. S. B. (2020). Pengaruh kecerdasan emosi, kecerdasan spiritual dan persekitaran keluarga terhadap stres akademik murid sekolah menengah. Malaysian Journal of Social Sciences and Humanities (MJSSH), 5(5), $12-23$.

Arika, Y. (2020, March 18). Lebih dari 849 juta siswa di dunia belajar di rumah. Kompas. Retrieved from https://kompas.id/baca/humaniora/dikbud/2020/03 /18/lebih-dari-849-juta-siswa-di-dunia-belajar-dirumah/

Asmara, C. G. (2020, March 25). Para siswa, simak surat terbaru Mendikbud Nadiem untuk kalian. CNBC Indonesia. Retrieved from https://www.cnbcindonesia.com/tech/2020032512 4101-37-147405/para-siswa-simak-surat-terbarumendikbud-nadiem-untuk-kalian

Chaterine, R. N. (2020, March 18). Siswa belajar dari rumah, KPAI: Anak-anak stres dikasih banyak tugas. Detik News. Retrieved from https://news.detik.com/berita/d-4944071/siswabelajar-dari-rumah-kpai-anak-anak-stres-dikasihbanyak-tugas

Fajar, T. (2020, March 25). Arti belajar di rumah di tengah wabah virus corona. Okezone News. Retrieved from https://news.okezone.com/read/2020/03/25/65/218 8872/arti-belajar-di-rumah-di-tengah-wabahvirus-corona

Hastini, L. Y., Fahmi, R., \& Lukito, H. (2020). Apakah 
pembelajaran menggunakan teknologi dapat meningkatkan literasi manusia pada generasi $\mathrm{Z}$ di Indonesia? Jurnal Manajemen Informatika (JAMIKA), 10(1), 12-28.

Izzah, L., Rahmawati, \& Humairoh, H. (2020). Pengaruh mendengarkan musik terhadap mood belajar pada mahasiswa manajemen dakwah UIN Suska Riau. Nathiqiyyah: Jurnal Psikologi Islam, 3(1), 1-6.

Kaufmann, R., \& Vallade, J. I. (2020). Exploring connections in the online learning environment: student perceptions of rapport, climate, and loneliness. Interactive Learning Environments, 115.

Morgan, H. (2020). Best Practices for Implementing Remote Learning during a Pandemic. The Clearing House: A Journal of Educational Strategies, Issues and Ideas, 93(3), 134-140.

Mukminina, M., \& Abidin, Z. (2020). Coping Kecemasan Siswa SMA dalam Menghadapi Ujian Tulis Berbasis Komputer (UTBK) Tahun 2019. Jurnal Al-Azhar Indonesia Seri Humaniora, 5(3), 110-116.

Pakpahan, R., \& Fitriani, Y. (2020). Analisa pemanfaatan teknologi informasi dalam pembelajaran jarak jauh di tengah pandemi virus corona covid-19. JISAMAR: Journal of Information System, Applied, Management, Accounting and Research, 4(2), 30-36.

Raharjo, D. B., \& Sari, R. R. N. (2020, March 19). Belajar online di tengah corona, ada siswa mengeluh tensi darah naik. Suara. Retrieved from https://www.suara.com/news/2020/03/19/205940/ belajar-online-di-tengah-corona-ada-siswamengeluh-tensi-darah-naik

Rusdiana, E., \& Nugroho, A. (2020). Respon pada Pembelajaran Daring bagi Mahasiswa Mata Kuliah Pengantar Hukum Indonesia. 31(1), 1-12.

Saifuddin, A. (2019). Psikologi agama: Implementasi psikologi untuk memahami perilaku beragama. Jakarta: Prenadamedia Group.

Shukla, T., Dosaya, D., Nirban, V. S., \& Vavilala, M. P. (2020). Factors extraction of effective teachinglearning in online and conventional classrooms. International Journal of Information and Education Technology, 10(6), 422-427.

Zhafira, N. H., Ertika, Y., \& Chairiyaton. (2020). Persepsi mahasiswa terhadap perkuliahan daring sebagai sarana pembelajaran selama masa karantina covid-19. Jurnal Bisnis Dan Kajian Strategi Manajemen, 4(1), 37-45. 